\title{
Demographic, Clinical and Immunological Manifestations of Systemic Lupus Erythematosus among Omani Population Single Tertiary Care Experience
}

\author{
Samata Al Dowaiki, Aftab Ahmed Siddiqi, Juma Al Kaabi, Umar Ahmed Siddiqui, \\ Mohammad Ahsan Usman Khan
}

ABSTRACT

OBJECTIVES: This study aimed to determine the demographic, clinical and immunological manifestations of SLE among the Omani population and to compare the results with a previous study in 2003and global data.

METHODOLOGY: This retrospective study included patients aged $>12$ years old with SLE who complied with the 2012 Systemic Lupus International Collaborating Clinics SLE criteria and presented to the Sultan Qaboos University Hospital, Muscat, Oman between January- December 2016. The cumulative frequency of disease manifestations and auto antibodies was determined. Published studies evaluating SLE manifestations in other countries (Gulf countries, India, UK, Italy and Australia) were collected for comparison.

RESULTS: A total of 285 patients were included in this study, $256(89.5 \%)$ were female and $29(10.5 \%)$ were male with a female: male ratio of 9:1. The median age was 33 years (age range: 14-69). The 10 year survival rate was found to be $99 \%$ with $6.8 \%$ of patients lost to follow up. More than $60 \%$ of the patients were from two highly populated regions: Al Batinah $(37 \%)$ and Muscat $(24 \%)$ governorate. The cumulative frequency of the clinical manifestations was as follows: haematological manifestations $(63 \%)$, arthritis $(62 \%)$, renal manifestations $(44 \%)$, serositis $(12.3 \%)$, alopecia $(26.3 \%)$, rash $(31 \%)$, oral ulcers $(11.9 \%)$ and neurological disorders $(15 \%)$. The cumulative frequency of the detected auto-antibodies was as follows: anti-nuclear antibodies(98\%), anti-double stranded DNA (81\%), extractable nuclear antigens (89\%), anti-histone (37\%), anti-smith (25\%), anti-Sjögren's syndrome A $(36 \%)$, anti-Sjögren's syndrome B(10.6\%), anti-nucleosome (35\%) and anti-Ribosomal antibodies $(23 \%)$. CONCLUSION: Comparing the above results to other studies, clinical and immunological manifestations of SLE in Oman are similar to other Gulf countries. There is an increased frequency of visceral (renal and neurological) involvement in the Gulf region compared to other geographic areas around the world.

KEY WORDS: Systemic lupus erythematosus, Clinical and immunological manifestations, Oman.

This article may be cited as: Dowaiki SA, Siddiqi AA, Kaabi JA, Siddiqui UA, Khan MAU. Demographic, Clinical and Immunological Manifestations of Systemic Lupus Erythematosus among Omani Population Single Tertiary Care Experience. J Liaquat Uni Med Health Sci. 2018;17(04):208-14. doi: 10.22442/jlumhs.181740579

\section{INTRODUCTION}

Systemic lupus Erythematosus (SLE) belongs to a spectrum of autoimmune disorders. It is a multisystem disease and it is affected by genetic, ethnic and environmental factors as shown in previous studies ${ }^{1}$. The disease severity and organ involvement vary throughout the world which reflect the multi factorial causes and triggers of the disease $e^{2,3}$.

SLE has a significant impact on quality of life (QOL). It affects the physical, psychological and social well-being of the patients. Additionally, it has an effect on economy as around $75 \%$ of patients with SLE retire before their expected age of retirement ${ }^{4}$.
The demographic variability of SLE has encouraged many descriptions of its pattern in different geographic areas around the world. Since 1990s, a number of studies evaluated SLE in the Gulf countries ${ }^{1,5,6}$. In 2003 a study was conducted to evaluate SLE pattern in Oman. Their results were comparable to those from other Gulf countries. SLE was characterized by more aggressive nature with younger age of onset when compared to other studies. It was found that at disease onset, $62 \%$ were under 20 years of age and almost half of the studied group had a family history of the disease ${ }^{1}$.

The different manifestation of SLE in the Gulf countries was explained by the raised incidence of the 
serotype human leukocyte antigen (HLA) DR2 in the population ${ }^{7}$. It is well known that HLA clustering within autoimmune diseases indicates a genetic predisposition but does not define the exact pathogenesis.

Abdwani R $2013^{8}$ described the geographical distribution of childhood-onset SLE in Oman. Geographical clustering of childhood-onset SLE was found in Al-Sharqia region, which constituted $41 \%$ of all cases in Oman. There were more affected males from the Sharqia region than from the rest of the country ( $42 \%$ versus $15 \%$ of patients). Also, Patients from Al-Sharqia region were diagnosed at an earlier age (6.4 versus 9.4 years) and had a stronger family history of SLE.

The primary aim of this study was to describe the demographic, clinical and immunological manifestations of SLE among Omani patients and to compare the results with those from the previous study conducted by Al-Maini M 2003', other Gulf countries and global data. The secondary aim was to evaluate the predictor status of auto antibodies for pathology.

\section{METHODOLOGY}

This is a retrospective cross sectional study. The study population was Omani patients who presented to the adult rheumatology clinic at the Sultan Qaboos University Hospital (SQUH) from January to December 2016. Patients who were 12 years or older and complied with the 2012 Systemic Lupus International Collaborating Clinics (SLICC) criteria were included. Patients with insufficient data in their medical records and patients with mixed connective tissue disease or overlap syndrome were excluded. All patients who met the eligibility criteria were included in the study. The demographics were comprised of age, gender and region of residency. The clinical profile of the patients was determined using definitions for clinical manifestations from the SLICC 2012 criteria definitions ${ }^{9}$.

For a patient's immunological status, anti-nuclear antibodies(ANA)results were defined as positive if the titre ratio was $\geq 1: 80$. Anti-ds (double stranded) DNA results were defined as positive if the Enzyme-Linked Immunosorbent Assay (ELISA) test was greater than double the normal reference range or 'crithidia' was above the reference range. Anti-phospholipid antibodies results were defined as positive if the values consistently remained positive.
Statistical Package for the Social Science (SPSS) version 22 (IBM Corp., Armonk, New York, USA) was used to analyse the data. Descriptive statistics were reported using frequency and percentage. Chi-square test was used to test the association between categorical variables. Significance level was set at 0.05 .

Ethical approval was received in June 2016 from the local research committee. Data analysis commenced from January 2017 to February 2017. The final review was in May 2017.

\section{RESULTS}

A total of 285 patients complied with the SLICC 2012 criteria and were included in this study. There were 265 females and 29 males with a female: male ratio of $9: 1$. The majority of patients $(61 \%)$ were from highly populated regions; Muscat and Al-Batinah. The majority of patients $(70 \%)$ were in childbearing age (20-40 years old). (Table I)

Based on SLICC criteria definitions and the available data, the cumulative frequency of affected organ systems among the study population were as follows: musculoskeletal (62\%), renal $(44.5 \%)$ and neurological [seizures, psychosis, and myelitis] (15\%). The majority of SLE patients were anaemic (haemoglobin $<11 \mathrm{~g} / \mathrm{dl}$ ) and lymphopenic $\left(<1.2 .10^{9} / \mathrm{L}\right)$. Thrombocytopenia was recorded in $8-12 \%$ of patients. A high inflammatory activity was observed in the majority of patients. The cumulative frequency of haematological manifestations, autoimmune haemolytic anaemia, thrombocytopenia and lymphopenia was $63 \%, 7.7 \%, 8.5 \%, 52.6 \%$, respectively. (Table II)

Common auto-antibodies found were ANA, anti-ds DNA, anti-smith, anti-histones, anti-ribonuclease $P$ protein $-A$, anti-Sjögren's syndrome $A$, anti-RO 52 , anti-nucleosome and anti-ribosomal antibodies.ANA titre was high $(\geq 1: 640)$ in $63 \%$ of patients. (Table III) Using the Chi-square test, a significant association between some auto antibodies and specific organ-pathogenesis was found. A significant association was found between anti-nucleosome antibodies and alopecia $[P=0.023] ; A N A$ and lymphopenia $(P=0.02)$; and anti-ribosomal antibodies and lymphopenia $(P=0.01)$. There was a significant association between anti-ribosomal antibodies and alopecia $(P=0.0001)$; and anti-ribosomal antibodies and oral ulcers $(P=0.004)$. Anti-ds DNA was mostly related to renal manifestations $(P=0.07)$. 
Samata Al Dowaiki, Aftab Ahmed Siddiqi, Juma Al Kaabi, Umar Ahmed Siddiqui, Mohammad Ahsan Usman Khan

TABLE I: DEMOGRAPHICS OF THE OMANI STUDY POPULATION $(n=285)$

\begin{tabular}{|c|c|}
\hline \multicolumn{2}{|l|}{ Gender distribution } \\
\hline Females & $256(89.9 \%)$ \\
\hline Males & $29(10.1 \%)$ \\
\hline Female to Male ratio & $9: 1$ \\
\hline \multicolumn{2}{|l|}{ Age distribution (yrs) } \\
\hline$<20$ & $8.8 \%$ \\
\hline $20-30$ & $32 \%$ \\
\hline $31-40$ & $38 \%$ \\
\hline $41-50$ & $14 \%$ \\
\hline $51-60$ & $5.6 \%$ \\
\hline$>60$ & $0.7 \%$ \\
\hline \multicolumn{2}{|c|}{ Regional distribution ( Governorate) } \\
\hline Al-Batinah & $37 \%$ \\
\hline Muscat & $24.2 \%$ \\
\hline Al-Sharqia & $16.8 \%$ \\
\hline Al-Dakhlia & $15.8 \%$ \\
\hline Al-Dhahira & $4.6 \%$ \\
\hline Dofar & $1.1 \%$ \\
\hline Musandam & $0.4 \%$ \\
\hline
\end{tabular}

Table II: Comparison of the cumulative frequency (\%) of haematological and serological manifestations in systemic lupus erythematosus patients between the current study (2006-2016) and Al-Maini et al's study $(2003)^{1}$.

\begin{tabular}{|l|c|c|}
\hline & $\begin{array}{c}\text { Al-Maini } \mathbf{M}^{\mathbf{1}} \\
\text { Study 2003 } \\
\mathbf{( \% )}\end{array}$ & $\begin{array}{c}\text { Current study } \\
(\mathbf{2 0 0 6 - 2 0 1 6 )} \\
\mathbf{( \% )}\end{array}$ \\
\hline Anaemia $(\mathrm{Hb}<11.0 \mathrm{~g} / \mathrm{dl})$ & 64.1 & 63.9 \\
\hline Lymphopenia $\left(<1.2 \cdot 10^{9} / \mathrm{L}\right)$ & 49 & 52.6 \\
\hline $\begin{array}{l}\text { Thrombocytopenia } \\
\left(<150 \cdot 10^{9} / \mathrm{L}\right)\end{array}$ & 12.7 & 8.1 \\
\hline Raised ESR $(>15 \mathrm{~mm} / \mathrm{hr})$ & 74 & 68.1 \\
\hline Lowered C3 & $65.5^{*}$ & $71^{* *}$ \\
\hline Lowered C4 & $33.3^{*}$ & $65^{* *}$ \\
\hline ALT $(>42 \mathrm{u} / \mathrm{l})$ & 6.4 & 5 \\
\hline
\end{tabular}

$H b=$ Haemoglobin; ESR = Erythrocyte Sedimentation Rate; $C=$ Complement; $A L T=$ Alanine Aminotransferase.
${ }^{*}$ Percentage of low complements $(C)$ in the current cohort study. ${ }^{* *}$ Percentage of cumulative frequency of low $C 4$ in the 10 year study period.

TABLE III: AUTO ANTIBODIES AND THEIR RESPECTIVE CUMULATIVE FREQUENCY AMONG THE STUDY POPULATION. $(\mathbf{n}=\mathbf{2 8 5})$

\begin{tabular}{|c|c|c|}
\hline Autoantibody type & $\begin{array}{l}\text { No. of patients } \\
\text { with a positive } \\
\text { result (No. of } \\
\text { patients tested) }\end{array}$ & $\begin{array}{l}\text { Percentage of } \\
\text { patients with } \\
\text { positive autoan- } \\
\text { tibodies out of } \\
\text { patients tested }\end{array}$ \\
\hline ANA & $281(285)$ & $98.6 \%$ \\
\hline \multicolumn{3}{|l|}{ Anti-ds DNA } \\
\hline ELISA & $231(285)$ & $81 \%$ \\
\hline Crithidia & $37(171)$ & 24.95 \\
\hline Rheumatoid Factor & $30(120)$ & $25 \%$ \\
\hline ENA & $251(282)$ & $89 \%$ \\
\hline Anti-Jo1 & $2(282)$ & $0.7 \%$ \\
\hline Anti-RNP-A & 39 (129) & $30 \%$ \\
\hline Anti-RNP-C & 33 (129) & $25.5 \%$ \\
\hline Anti-RNP & $59(282)$ & $20 \%$ \\
\hline Anti-Ku & $23(135)$ & $17 \%$ \\
\hline Anti-Mi2 & $8(135)$ & $5.9 \%$ \\
\hline Anti-SCL70 & $6(282)$ & $2.1 \%$ \\
\hline Anti-SS-A (Ro) & $102(282)$ & $36.5 \%$ \\
\hline Anti-SS-B (La) & $30(282)$ & $10.6 \%$ \\
\hline Anti-Smith & $90(282)$ & $31 \%$ \\
\hline Anti-Histones & $106(282)$ & $37.5 \%$ \\
\hline Anti-Nucleosomes & $58(165)$ & $35 \%$ \\
\hline Anti-PCNA & $6(168)$ & $3.6 \%$ \\
\hline Anti-Ro52 & 39 (165) & $23 \%$ \\
\hline Anti-Centromere & $5(282)$ & $1.7 \%$ \\
\hline Anti-Ribosomes & $65(282)$ & $26 \%$ \\
\hline \multicolumn{3}{|c|}{ Anti-Phospholipid antibodies } \\
\hline Lupus anticoagulants & $34(239)$ & $14 \%$ \\
\hline Anti-Cardiolipin & $55(246)$ & $22.3 \%$ \\
\hline Anti-B2 glycoprotein & $42(242)$ & $17.3 \%$ \\
\hline
\end{tabular}

$A N A=$ Antinuclear Antibodies; $d s=$ double stranded; ELISA = Enzyme-Linked Immunosorbent Assay; ENA = Extractable Nuclear Antigens; $R N P=$ Ribonuclease $P$ Protein; SCL70 = anti-topoisomerase l; SS = Sjögren's syndrome; PCNA = Proliferating Cell Nuclear Antigen . 


\section{DISCUSSION}

This study aimed to describe the manifestations of SLE among the Omani population over a period of 10 years. This study was conducted in a tertiary care centre, SQUH and showed that most patients were females of child bearing age and that the majority lived in highly populated governates, Al-Batinah and Muscat. The cumulative frequency of haematological and inflammatory markers from the present study was similar to those from Al-Maini M 2003 ${ }^{1}$. Both studies showed that the majority of SLE patients were anaemic, lymphopenic and had a high erythrocyte sedimentation rate and hypo-complimentemia.

When comparing SLE manifestations in Oman to the Gulf and other countries, haematological and musculoskeletal manifestations appear to be similar in frequency ${ }^{1,10-17}$. Renal disease, however, was more common in the Gulf countries and India compared to Europe and Australia. It was recorded in $44 \%, 37 \%$, $43 \%, 63 \%$ and $69 \%$ of the patients in Oman, Kuwait, United Arab Emirates (UAE), Kingdom of Saudi Arabia (KSA) and India respectively ${ }^{10-13}$. In contrast, renal disease was lower in frequency in Italy, United
Kingdom (UK) and Australia. It was found in $27 \%, 22 \%, 16-22 \%$ of the patients, respectively ${ }^{15-17}$. (Table IV)

Similar to renal disease, neurological manifestations of SLE appeared to be more common in the Gulf countries when compared to other geographic areas. Neurological diseases manifested in 15\%, 23\%, 15\% and $26 \%$ of patients with SLE in Oman, Kuwait, UAE and $\mathrm{KSA}$, respectively ${ }^{1,10-12}$, however, they are less frequently reported in other countries including India. Neurological diseases were reported in $4.5 \%, 8 \%$, $10 \%$ and $16-5 \%$ of SLE patients in India, Italy, UK and Australia $^{13-17}$.

Anti-ds DNA antibodies and anti-Smith antibodies were more prevalent in Oman and other Gulf countries. These differences may contribute to the more visceral organ involvement in the region. Anti-ds DNA was shown to indicate disease activity, to be associated with lupus nephritis and to predict SLE flare up.

This study was comparable to the study which was conducted by Al-Maini M 2003', but there was a decrease in the frequency of neurological

Table IV: Frequency in percentages of autoimmune serological markers in systemic lupus erythematosus patients from different countries. ANA antinuclear antibody, Sm, SS-A, SS-B, RNP individual components of extractable nucleic acids (ENA), APL anti-phospholipid, ACA anti-cardiolipin antibody, ab2GPI anti-beta-2 glycoprotein I

\begin{tabular}{|l|c|c|c|c|c|c|c|c|c|c|}
\hline \multicolumn{1}{|c|}{ Country } & $\begin{array}{c}\text { ANA } \\
(\%)\end{array}$ & $\begin{array}{c}\text { ds-DNA } \\
(\%)\end{array}$ & $\begin{array}{c}\text { Anti-Sm } \\
(\%)\end{array}$ & SS-A (\%) & SS-B (\%) & $\begin{array}{c}\text { RNP } \\
(\%)\end{array}$ & $\begin{array}{c}\text { Musculo- } \\
\text { skeletal } \\
(\%)\end{array}$ & $\begin{array}{c}\text { Haemat- } \\
\text { ological } \\
(\%)\end{array}$ & $\begin{array}{c}\text { Renal } \\
\text { Disorders } \\
(\%)\end{array}$ & $\begin{array}{c}\text { Neuro- } \\
\text { Manifesta- } \\
\text { tions (\%) }\end{array}$ \\
\hline $\begin{array}{l}\text { Oman (current } \\
\text { study) }\end{array}$ & 98 & $\begin{array}{c}81 \\
(\text { ELISA) }\end{array}$ & 31 & 36 & 10 & 20 & 62 & 63 & 44 & 15 \\
\hline $\begin{array}{l}\text { Oman } \\
(2003)\end{array}$ & 97 & $\begin{array}{c}92 \\
(\text { Crithidia }\end{array}$ & 50 & 44 & 41 & 23 & 53 & 33 & 50 & 33 \\
\hline Kuwait $^{10}$ & 97 & 36 & 13 & 35 & 13 & 13 & 87 & 53 & 37 & 23 \\
\hline UAE $^{11}$ & 92 & 88 & 19 & 52 & 19 & 40 & 86 & 61 & 43 & 15 \\
\hline KSA $^{12}$ & 98 & 93 & 40 & NA & NA & NA & 91 & 70 & 63 & 26 \\
\hline India $^{13,14}$ & 97 & 53 & 14 & 8 & 8 & 20 & 52 & 72 & 69 & 4.6 \\
\hline Italy $^{15}$ & 97 & 83 & 16 & 28 & 13 & 20 & 61 & 55 & 27 & 8 \\
\hline UK $^{16}$ & 97 & 54 & 3 & 11 & 11 & 22 & 63 & 44 & 22 & 10 \\
\hline $\begin{array}{l}\text { Australia } \\
\text { sians Cauca- } \\
\text { Aborigines }\end{array}$ & 100 & 66 & 0 & 50 & 16 & 0 & 83 & 46 & 16 & 16 \\
\hline
\end{tabular}

$A N A=$ Antinuclear Antibodies; $d s=$ double stranded; $S m=$ Smith; ELISA = Enzyme-Linked Immunosorbent Assay; $R N P=$ Ribonuclease $P$ Protein; $S S=$ Sjögren's syndrome;; UAE = United Arab Emirates; $K S A=$ Kingdom of Saudi Arabia; UK = United Kindgom. 
Samata Al Dowaiki, Aftab Ahmed Siddiqi, Juma Al Kaabi, Umar Ahmed Siddiqui, Mohammad Ahsan Usman Khan

\begin{tabular}{|c|c|c|}
\hline \multicolumn{3}{|c|}{ Summary of the outcome and association of the Overall number of the study population with SLE (2006 -2016) } \\
\hline Category & Sub-category & Number of patients \\
\hline Mortality & $\begin{array}{l}\text { Sepsis } \\
\text { Pulmonary Haemorrhage } \\
\text { Stroke \& Myasthenia Gravis } \\
\text { Interstitial lung disease } \\
\text { Necrotizing fasciitis }\end{array}$ & $\begin{array}{l}4 \\
1 \\
1 \\
1 \\
1\end{array}$ \\
\hline Steroid related morbidity & $\begin{array}{l}\text { avascular necrosis } \\
\text { steroid related psychosis } \\
\text { baby congenital abnormality } \\
\text { osteoporosis }\end{array}$ & $\begin{array}{l}1 \\
1 \\
1 \\
2\end{array}$ \\
\hline Malignancy (4 cases) & $\begin{array}{l}\text { Lymphoma } \\
\text { Breast Cancer } \\
\text { Pupillary thyroid cancer and meningioma }\end{array}$ & $\begin{array}{l}2 \\
1 \\
1\end{array}$ \\
\hline Thrombosis & $\begin{array}{l}\text { DVT } \\
\text { PE } \\
\text { Cerebral sinus thrombosis }\end{array}$ & $\begin{array}{l}8 \\
3 \\
1\end{array}$ \\
\hline Secondary APLS & $\begin{array}{l}\text { Abortion } \\
\text { Primary infertility } \\
\text { Still birth } \\
\text { Secondary infertility } \\
\text { Intra-uterine fetal death }\end{array}$ & $\begin{array}{l}19 \\
3 \\
1 \\
2 \\
1\end{array}$ \\
\hline Cardiac disease & $\begin{array}{l}\text { Pericardial effusion } \\
\text { Ischemic heart disease } \\
\text { Heart Failure/Dilated Cardiomyopathy. } \\
\text { Mitral stenosis }\end{array}$ & $\begin{array}{l}8 \\
4 \\
3 \\
2\end{array}$ \\
\hline Neurological disorders & $\begin{array}{l}\text { Seizures } \\
\text { Stroke } \\
\text { Psychosis } \\
\text { Depression } \\
\text { Cerebral Vasculitis } \\
\text { TIA } \\
\text { Optic Neuritis } \\
\text { Transverse Myelitis }\end{array}$ & $\begin{array}{l}14 \\
8 \\
8 \\
6 \\
5 \\
2 \\
1 \\
1\end{array}$ \\
\hline Pulmonary disease diseases & $\begin{array}{l}\text { ILD } \\
\text { Pleural effusion } \\
\text { Pulmonary Haemorrhage }\end{array}$ & $\begin{array}{l}7 \\
4 \\
3\end{array}$ \\
\hline $\begin{array}{l}\text { Association with other Autoimmune disease } \\
\text { (excluding connective tissue diseases) }\end{array}$ & $\begin{array}{l}\text { Hypothyroidism } \\
\text { Autoimmune Hepatitis } \\
\text { DM } \\
\text { Coeliac disease } \\
\text { Myasthenia Gravis } \\
\text { Pernicious anaemia } \\
\text { Autoimmune pancreatitis } \\
\text { Crohn's disease }\end{array}$ & $\begin{array}{l}30 \\
10 \\
6 \\
6 \\
6 \\
2 \\
2 \\
1\end{array}$ \\
\hline Necrotizing Fasciitis & $\begin{array}{l}\text { fatal Necrotizing Fasciitis } \\
\text { Respond to medical Treatment }\end{array}$ & $\begin{array}{l}1 \\
2\end{array}$ \\
\hline Miscellaneous Coexisted illness/disease & $\begin{array}{l}\text { Rickettsia infection } \\
\text { Q fever } \\
\text { Kikuchi disease } \\
\text { Neurofibromatosis. }\end{array}$ & $\begin{array}{l}1 \\
1 \\
1 \\
1\end{array}$ \\
\hline
\end{tabular}


manifestations in this study compared to the previous one $(15 \%$ versus $33 \%)$. This can be explained by the difference in the methodological criteria which was used for the clinical manifestations. Stroke is not a clinical criterion in the 2012 SLICC criteria. Therefore patients manifesting with stroke was not recorded in this study. On the contrary, haematological manifestations appeared to be more frequent in this study. This can be explained by the longer duration of this present study which allowed for more cumulative frequency of haematological manifestations of SLE, mainly lymphopenia.

However, this study was subjected to certain limitations. Inconsistency of data recording made the retrospective review of some information difficult. The development of new diagnostic criteria and laboratory tests over time has limited the comparison between various studies. This study was conducted in a tertiary care centre. This might have led to an over estimation of organ involvement in SLE in the Omani population.

\section{CONCLUSION}

We advise genetic counselling in Omani SLE induced population. We suggest increasing public awareness about the role of genetics in the pathogenesis of many disorders including SLE. These efforts can decrease the burden of genetic predisposition by encouraging non-consanguinity for family planning in Oman.

\section{REFERENCES}

1. Almaini M, El-Ageb EM, Al-Wahaibi S, Al-Farsi Y, Richens ER. Demographic, autoimmune and clinical profiles of patients with systemic lupus erythematosus in Oman. Rheumatol Int. 2003; 23 (4):186-91. doi: 10.1007/s00296-003-0303-6. 2003.

2. Ceccarelli F, Perricone C, Borgiani P, Ciccacci C, Rufini S, Cipriano E, et al. Genetic Factors in Systemic Lupus Erythematosus: Contribution to Disease Phenotype. J Immunol Res. 2015; 2015:745647. doi: 10.1155/2015/745647.

3. Housay M, DeGuire P, Lyon-Callo S, Wang L, Marder W, McCune WJ, et al. Incidence and Prevalence of Systemic Lupus Erythematosus Among Arab and Chaldean Americans in Southeastern Michigan: The Michigan Lupus Epidemiology and Surveillance Program. Am J Public Health. 2015; 105(5): e74-e79. doi: 10.2105/AJPH.2014.302423.
4. Panopalis $P$, Clarke A, Quality of life is systemic lupus erythematsus. Clin Dev Immunol 2006; 13 (2 -4): 321-4. doi: 10.1080/17402520600877760.

5. Al Dhanhani AM, Agarwal M, Othman YS, Bakoush O. Incidence and prevalence of systemic lupus erythematosus among the native Arab population in UAE. Lupus. 2017; 26(6): 664-669. doi: $10.1177 / 0961203316678677$.

6. Stojan G, Petri M. Epidemiology of systemic lupus erythematosus: An update. Curr Opin Rheumatol 2018; 30(2): 144-150. doi: 10.1097/ BOR.0000000000000480.

7. Tikly M, Navarra SV. Lupus in the developing world--is it any different? Best Pract Res Clin Rheumatol 2008; 22(4): 643-55. doi: 10.1016/ j.berh.2008.05.003.

8. Abdwani R, Al-Abrawi S, Sharaf WS, Al- Zakwani I. Geographical clustering of juvenile onset systemic lupus erythematosus within the Sultanate of Oman. Oman Med J 2013; 28(3):199203. doi: $10.5001 / o m j .2013 .54$.

9. Petri $M$, Megder L. Classification criteria for Systemic Lupus Erythematosus: A Review. Lupus. 2004; 13(11): 829-37.

10. Al-Jarallah $\mathrm{K}$, Al-Awadi A, Siddiqui $\mathrm{H}$, Al-Salim I, Shehab D, Umamaheswaran I, et al. Systemic lupus erythematosus in Kuwait--hospital based study. Lupus. 1998; 7(7): 434-8.

11. AISaleh J, Jassim V, EISayed M, Saleh N, Harb D. Clinical and immunological manifestations in 151 SLE patients living in Dubai. Lupus; 17(1): 626.

12. Alballa SR. Systemic lupus erythematosus in Saudi patients. Clin Rheumatol. 1995; 14(3): 342346.

13. Agrawal SR, Tiewsoh I, Rajput A, Jain A. A crosssectional hospital based study of clinical and immunological profile of systemic lupus erythematosus patients from central rural India. Indian J Allergy Asthma Immunol. 2013; 27(1): 33-7.

14. Kosaraju K, Shenoy S, Suchithra U. A cross-sectional Hospital based study of Autoantibody profile and clinical manifestations of systemic lupus erythematosus in south Indian patients. Indian J Med Microbiol 2010; 28(3):2457. doi:10.4103/0255-0857.66487.

15. Sebastiani G, Prevete I, Piga M, luliano A, Bettio S, Bortoluzzi A, et al. Early Lupus Project - A multicentre Italian study on systemic lupus 
erythematosus of recent onset. Lupus 2015; 24 (12): 1276-82. doi: 10.1177/0961203315585817.

16. Hopkinson ND, Doherty M, Powell R. Clinical features and race- specific incidence/ prevalence rates of systemic lupus erythematosus in a geographically complete cohort of patients. Ann
Rheum Dis 1994; 53(10): 675-80.

17. Segasothy M, Phillips PA. Systemic lupus erythematosus in Aborigines and Caucasians in central Australia: a comparative study. Lupus 2001; 10(6): 439-44.

AUTHOR AFFILIATION:
Dr. Samata Al Dowaiki
Resident, Department of Internal Medicine
Ministry of Health
Sultan Qaboos University Hospital.
Dr. Aftab Ahmed Siddiqi (Corresponding Author)
Senior Consultant, Department of Medicine
Sultan Qaboos University Hospital.
Email: aftabsidpk@hotmail.com
Dr. Juma Al Kaabi
Department of Medicine, Ministry of Health.
Buraimi Hospital.
Dr. Umar Ahmed Siddiqui
Fourth Year MBBS
CMH Medical College and Institute of Dentistry
Lahore, Punjab-Pakistan.
Dr. Mohammad Ahsan Usman Khan
Demonstrator Anatomy Department
Liaquat College of Medicine and Dentistry
Karachi, Sindh-Pakistan.

